\title{
Total Synthesis of Lignan Lactone (-)-Hinokinin
}

\author{
Qi-Long Zhou $\cdot$ Hui-Jing Wang $\cdot$ Pei Tang $\cdot$ \\ Hao Song · Yong Qin
}

Received: 3 September 2015 / Accepted: 22 September 2015/Published online: 12 October 2015

(C) The Author(s) 2015. This article is published with open access at Springerlink.com

\begin{abstract}
This research paper is aimed at studying the total synthesis of pharmacologically active lignan (-)-hinokinin. The synthesis features a three-step cascade reaction involving highly stereoselective Michael addition, anion-oxidative hydroxylation, and oxygen anion cyclization to construct the pivotal butyrolactonimidate intermediate.
\end{abstract}

Keywords Lignan · Hinokinin · Total synthesis · Cascade reaction

\section{Introduction}

Lignans are a large class of natural products that were isolated from many plants [1, 2] (Fig. 1). They display diverse biological activities, especially antiviral and antitumor properties. For example, hinokinin (1) [3-5] has been found to exhibit antileukemic, antiviral, antifungal, and pesticidal activities [6-26]. Mammalian lignin enterolactone (2), which is formed by the action of intestinal bacteria from plant lignan precursors present in the diet, inhibit breast cancer and colon cancer, and may also inhibit cardiovascular disease [27, 28]. Furthermore, podophyllotoxin (3), steganacin (4) and tetrahydrofuran lignan burseran (5) show strong cytotoxic activity against

Electronic supplementary material The online version of this article (doi:10.1007/s13659-015-0073-3) contains supplementary material, which is available to authorized users.

\section{Q.-L. Zhou $\cdot$ H.-J. Wang $\cdot$ P. Tang $(\varangle)$}

Innovative Drug Research Centre, Chongqing University, Chongqing 401331, China

e-mail: tangpei@cqu.edu.cn

\section{H. Song · Y. Qin $(\bowtie)$}

Key Laboratory of Drug Targeting and Drug Delivery Systems of the Ministry of Education, West China School of Pharmacy, Sichuan University, Chengdu 610041, China

e-mail: yongqin@scu.edu.cn various cancer cell lines by preventing the normal function of the mitotic spindle [29-36]. In addition, the furofuran lignan methyl piperitol (6) possesses platelet activating factor (PAF) antagonist activity [37]. Due to their interesting biological activities, several members of this family of natural products and their analogs have therefore been the target of extensive synthetic research [38-47].

We recently developed a one-pot, three-step cascade reaction from enantiomerically pure $(R)$ - $N$-tert-butanesulfinyl imidates 7 and $\alpha, \beta$-unsaturated diesters 8 [48] to generate butyrolactonimidates 11 (Scheme 1). This reaction proceeded through highly stereoselective Michael addition (7-9), followed by anion-oxidative hydroxylation (9-10) and oxygen anion cyclization (10-11). The synthesized butyrolactonimidates $\mathbf{1 1}$ are versatile intermediates for preparing substituted butyrolactones and furans. We also used this approach to achieve the concise total synthesis of natural product (-)-nephrosteranic acid [48]. In this paper, we report the total synthesis of lignan lactone (-)-hinokinin 1 as shown in Schemes 2 and 3.

\section{Results and Discussion}

We began our synthesis with the preparation of enantiopure (R)-N-tert-butanesulfinyl imidate 14 (Scheme 2): treatment of the known nitrile $\mathbf{1 2}[49,50]$ with gaseous $\mathrm{HCl}$ in 
Fig. 1 Representive lignans with pharmacological activities<smiles>O=C1OC[C@H](Cc2ccc3c(c2)OCO3)C1Cc1ccc2c(c1)OCO2</smiles>

hinokinin (1)<smiles>O=C1OC[C@H](Cc2cccc(O)c2)C1Cc1cccc(O)c1</smiles>

enterolactone (2)<smiles></smiles>

podophyllotoxin (3)<smiles></smiles>

steganacin (4)<smiles>COc1cc(C[C@@H]2COC[C@H]2Cc2ccc3c(c2)OCO3)cc(OC)c1OC</smiles>

burseran (5)<smiles>COc1ccc([C@H]2OC[C@H]3[C@H]2CO[C@H]3c2ccc3c(c2)OCO3)cc1OC</smiles>

Scheme 1 Synthesis of butyrolactonimidates $\mathbf{1 1}$ via the three-step cascade reaction

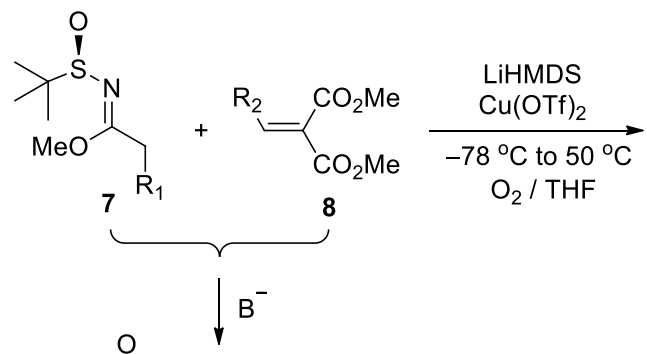<smiles>[R]C(C(=N[Si](O)C(C)(C)C)OC)C([R])C([R])C(OC)OC</smiles>

9

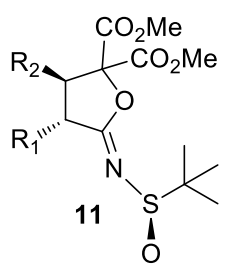
cyclization

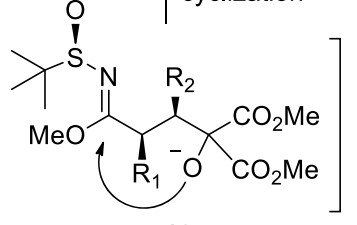

10 methanol yielded a good amount of trimethylorthoester intermediate [51], subsequent condensation of $(R)$-tertbutanesulfinamide $\mathbf{1 3}$ and the corresponding trimethylorthoester with a catalytic amount of $p$-TsOH without solvent afforded chiral $(R)$ - $N$-tert-butanesulfinyl imidate $\mathbf{1 4}$ in $76 \%$ overall yield [52-54]. With the $N$-sulfinyl imidate 14 in hand, we focused our attention on the construction of the pivotal butyrolactonimidate, as shown in Scheme 2. Firstly, we performed the one pot protocol between 14 and the known $\alpha, \beta$-unsaturated diester $15[55,56]$ under optimal condition [48] \{LiHMDS (5.0 equiv), $-78^{\circ} \mathrm{C}$; $\mathrm{Cu}(\mathrm{OTf})_{2}\left(5.0\right.$ equiv), -78 to $\left.60{ }^{\circ} \mathrm{C}\right\}$ to afford the desired butyrolactonimidate $\mathbf{1 6}$ in low yield (20\%), due to the isomerization of double bond in $\mathbf{1 5}$ under excess LiHMDS. To our delight, the stepwise procedure provided a satisfactory result. Indeed, a LiHMDS-mediated highly stereoselective Michael addition of 14-15 produced adduct 17 in $80 \%$ yield as the dominant stereoisomer (dr 55:2:1:0 by
LC-MS). Next, the resulting Michael adduct underwent the $\mathrm{Cu}(\mathrm{OTf})_{2}$-mediated anion-oxidative hydroxylation and oxygen anion cyclization to deliver $\mathbf{1 6}$ in $83 \%$ yield.

With the pivotal butyrolactonimidate $\mathbf{1 6}$ in hand, the synthesis of natural product (-)-hinokinin 1 was investigated (Scheme 3). The chiral tert-butylsulfinyl moiety in 16 was readily removed by TFA in $\mathrm{CH}_{2} \mathrm{Cl}_{2}$ to afford butyrolactone $\mathbf{1 8}$ in $80 \%$ yield. Krapcho demethoxycarbonylation of 18 with $\mathrm{LiCl}$ in DMSO afforded 19 in $90 \%$ yield as a 5:1 mixture of epimers [57-59], as determined by ${ }^{1} \mathrm{H}$ NMR spectroscopy. The mixture of epimers could not be separated by chromatography, however this would prove to be inconsequential since this carbon would become sp2 hybridized in subsequent steps. Reduction of the ester group in mixture 19 with $\mathrm{NaBH}_{4}$ in $\mathrm{MeOH}$ gave alcohol 20 in $78 \%$ yield. Subsequent reduction of the lactone group in 20 using $\mathrm{InBr}_{3}$ and $\mathrm{Et}_{3} \mathrm{SiH}$ in $\mathrm{CHCl}_{3}$ generated the desired furan $\mathbf{2 1}$ in $60 \%$ yield as a mixture 


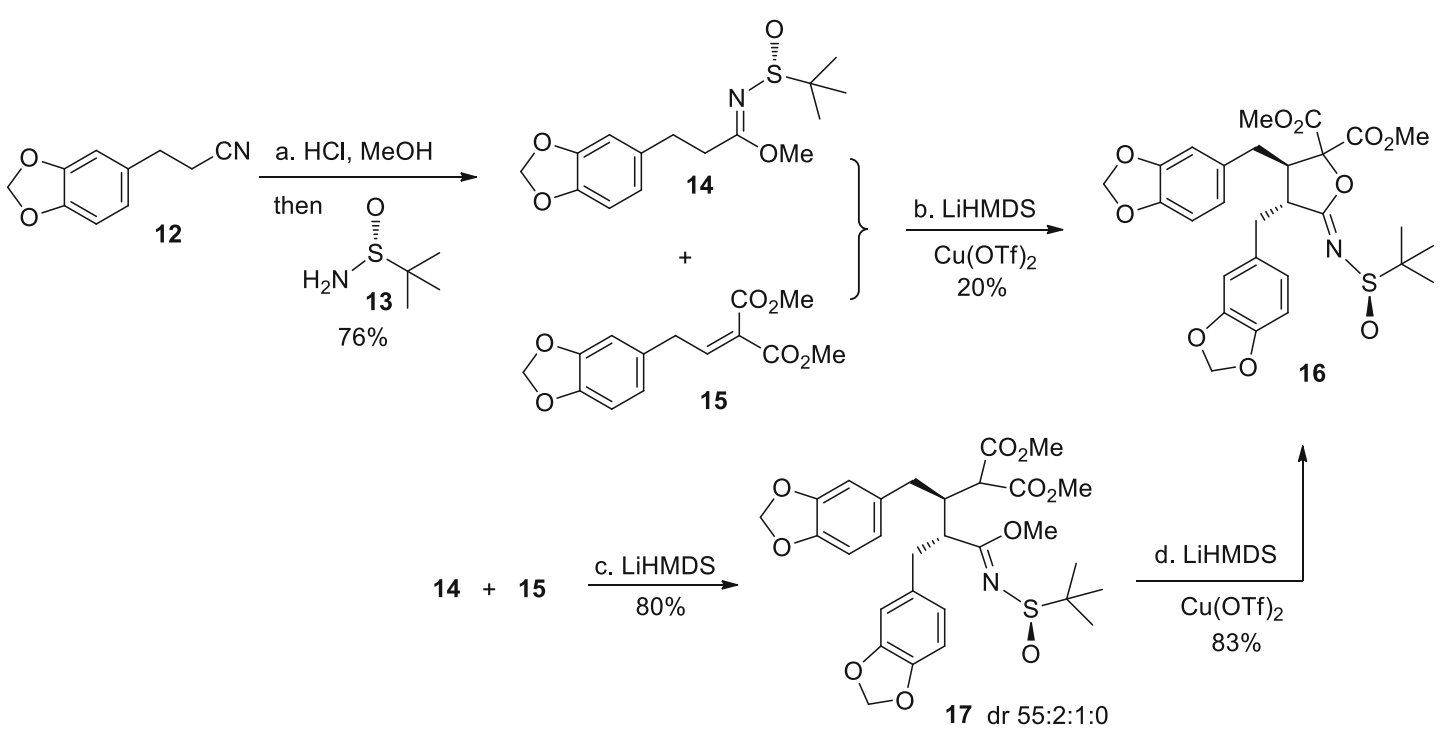

Scheme 2 Synthesis of butyrolactonimidate 16. Reagents and conditions: a $\mathrm{HCl}$ (gas), $\mathrm{MeOH}, 0{ }^{\circ} \mathrm{C}, 24 \mathrm{~h}$; $\mathrm{MeOH}$, r.t., $48 \mathrm{~h}$; then $(R)-$ tert-butanesulfinamide $13, p$-TsOH (0.05 equiv), neat, $60{ }^{\circ} \mathrm{C}, 24 \mathrm{~h}$, $76 \%$ in 2 steps; b LiHMDS (5.0 equiv), THF, $-78{ }^{\circ} \mathrm{C}, 0.5 \mathrm{~h}$, then
$\mathrm{Cu}(\mathrm{OTf})_{2}\left(5.0\right.$ equiv), -78 to $60{ }^{\circ} \mathrm{C}, 24 \mathrm{~h}, 20 \%$. c LiHMDS $(2.2$ equiv), THF, $-78{ }^{\circ} \mathrm{C}, 12 \mathrm{~h}, 80 \%$; d LiHMDS (3.3 equiv), THF, $-78{ }^{\circ} \mathrm{C}, 0.5 \mathrm{~h}$, then $\mathrm{Cu}(\mathrm{OTf})_{2}\left(5.0\right.$ equiv), -78 to $60{ }^{\circ} \mathrm{C}, 24 \mathrm{~h}, 83 \%$. LiHMDS Lithium hexamethyldisilazide, THF tetrahydrofuran<smiles>COC(=O)C1(C(=O)OC)OC(=O)[C@H](Cc2ccc3c(c2)OCO3)[C@H]1Cc1ccc2c(c1)OCO2</smiles>

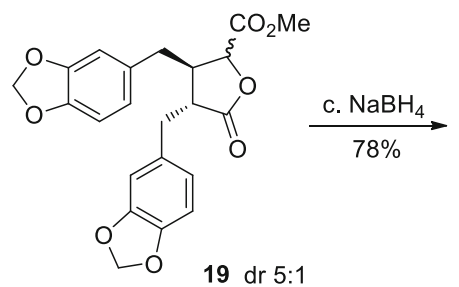<smiles>O=C1O[C@H](CO)[C@H](Cc2ccc3c(c2)OCO3)[C@H]1Cc1ccc2c(c1)OCO2</smiles>

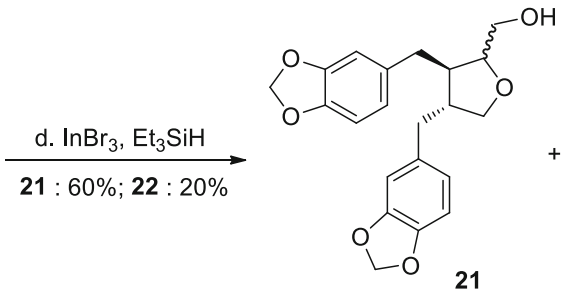

21

Scheme 3 Synthesis of (-)-hinokinin (1). Reagents and conditions: a TFA (10.0 equiv), $\mathrm{CH}_{2} \mathrm{Cl}_{2}, 0{ }^{\circ} \mathrm{C}$ to r.t., $80 \%$; b $\mathrm{LiCl}$ (5.0 equiv), DMSO, $100{ }^{\circ} \mathrm{C}, 8$ h, $90 \%$; $\mathrm{NaBH}_{4}$ (2.5 equiv), $\mathrm{MeOH}, 0{ }^{\circ} \mathrm{C}, 10 \mathrm{~h}$, $78 \%$; d $\operatorname{InBr}_{3}$ (0.05 equiv), $\mathrm{Et}_{3} \mathrm{SiH}$ (5 equiv), $\mathrm{CHCl}_{3}$, sealed tube,

of epimers [60, 61]. Interestingly, besides furan 21, further aromatic oxidative coupling proceeded under this condition to deliver compound $\mathbf{2 2}$ in $20 \%$ yield, which possessed the tetracyclic scaffold of dibenzocyclooctadiene lignans such as steganacin 4 (Fig. 1). The generation of 22 presumably resulted from the introduction of oxygen under this reductive condition, and the amount of $\mathbf{2 2}$ was considerably increased (TLC monitoring) when oxygen was intentionally bubbled into the reaction tube. Finally, heating of $\mathbf{2 1}$ with excess PCC in toluene completed the total synthesis of<smiles>OC[C@H]1OC[C@@H]2Cc3cc4c(cc3-c3cc5c(cc3C[C@H]12)OCO5)OCO4</smiles>

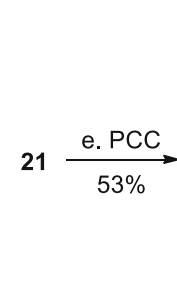

$60{ }^{\circ} \mathrm{C}, 2 \mathrm{~h}, 60 \%$ for $21,20 \%$ for 22; e PCC (5.0 equiv), PhMe, $80{ }^{\circ} \mathrm{C}, 5 \mathrm{~h}, 53 \%$. LiHMDS Lithium hexamethyldisilazide, THF tetrahydrofuran, TFA trifluoroacetic acid, DMSO dimethyl sulfoxide, $P C C$ pyridinium chlorochromate

lignan lactone (-)-hinokinin 1 in acceptable yield [62, 63], which displayed identical spectral properties to the reported data $[3-5,18,21,24,26]$.

\section{Conclusion}

In summary, we accomplished the total synthesis of the lignan lactone (-)-hinokinin $\mathbf{1}$ in 8 steps. The synthesis is based on a three-step cascade reaction involving highly 
stereoselective Michael addition, anion-oxidative hydroxylation, and oxygen anion cyclization to construct the pivotal butyrolactonimidate 16. The strategy we developed may find use in the synthesis of other pharmacologically active lignans.

\section{Experiment Section}

All commercially available reagents were used without further purification. All solvents were dried and distilled before use; THF was distilled from sodium. Chromatography was conducted by using 200-300 mesh silica gel. Petroleum ether refers to the $60-90{ }^{\circ} \mathrm{C}$ boiling fraction. All new compounds gave satisfactory spectroscopic analyses (IR, ${ }^{1} \mathrm{H}$ NMR, ${ }^{13} \mathrm{C}$ NMR, HRMS). IR spectra were recorded on a FT IR spectrometer. NMR spectra were recorded on 600/400 MHz NMR spectrometers. HRMS spectra were obtained by the ESI-TOF method. Experimental conditions and spectral data were published previously for compounds 12 [49, 50] and 15 [55, 56].

4.1 Methyl $(R, Z)-3$-(benzo[d][1,3]dioxol-5-yl)- $N$-(tertbutylsulfinyl)propanimidate (14)

(1) A mixture of the chosen nitrile 12 (28.60 mmol, 1.0 equiv) and methanol (37.00 mmol, 1.3 equiv) was charged in a $50 \mathrm{~mL}$ flask, and cooled in an ice bath. Gaseous $\mathrm{HCl}$ was slowly bubbled into the methanolic solution of the nitrile for $20 \mathrm{~min}$. The resulting mixture was kept at $0{ }^{\circ} \mathrm{C}$ for $24 \mathrm{~h}$. Then, the excess of methanol and $\mathrm{HCl}$ was removed by washing with $\mathrm{Et}_{2} \mathrm{O}$, white solid imidate hydrochloride was separated. The product was dried under vacuum at $\mathrm{rt}$, and used as such for the subsequent methanolysis step.

(2) At $\mathrm{rt}$, a mixture of methanol $(10 \mathrm{~mL})$ and the solid imidate hydrochloride was set to react under stirring for $48 \mathrm{~h}$. A clear solution was obtained. White solid (ammonium chloride) was formed during the reaction. Then, the mixture was filtered to cleavage $\mathrm{NH}_{4} \mathrm{Cl}$ and washed with $\mathrm{Et}_{2} \mathrm{O}$. The solvent was removed in vacuo to get the colorless oil trimethylintermediate $(6.5 \mathrm{~g}, 90 \%)$.

(3) Under $\mathrm{N}_{2}$, to neat trimethyl-intermediate $(9.84 \mathrm{mmol}$, 2 equiv) was added $(R)$-tert-butanesulfinamide 13 (4.92 mmol, 1 equiv) and $p$-TsOH $(0.25 \mathrm{mmol}, 0.05$ equiv). The reaction mixture was kept at $60{ }^{\circ} \mathrm{C}$ for $24 \mathrm{~h}$. The resulting residue was purified by column chromatography (silica gel) to give $14(1.3 \mathrm{~g}, 84 \%)$ as a colorless oil. $[\alpha]_{D}^{23}-97.0\left(c 0.22, \mathrm{CH}_{2} \mathrm{Cl}_{2}\right) ;{ }^{1} \mathrm{H} \mathrm{NMR}$ $\left(400 \mathrm{MHz}, \mathrm{CDCl}_{3}\right) \delta 6.64-6.72(\mathrm{~m}, 3 \mathrm{H}), 5.09(\mathrm{~s}, 2 \mathrm{H})$, $3.51(\mathrm{~s}, 3 \mathrm{H}), 2.86-2.93(\mathrm{~m}, 4 \mathrm{H}), 1.18(\mathrm{~s}, 9 \mathrm{H}) ;{ }^{13} \mathrm{C} \mathrm{NMR}$ $\left(100 \mathrm{MHz}, \mathrm{CDCl}_{3}\right) \delta 175.6,147.6,146.0,133.8,121.2$, 108.8, 108.2, 100.8, 55.8, 54.1, 34.8, 32.1, 21.8; HRMS $[\mathrm{M}+\mathrm{Na}]^{+}$calcd for $\mathrm{C}_{15} \mathrm{H}_{21} \mathrm{NNaO}_{4} \mathrm{~S} 334.1083$, found 334.1084; IR (KBr) 2948, 1608, 1491, 1443, 1245, 1076, 1040, 926, 810, 750, 591.

4.2 Dimethyl 2-((2R,3R,Z)-1-(benzo[d][1,3]dioxol-5yl)-3-(benzo[ $d][1,3]$ dioxol-5-ylmethyl)-4- $(((R)-$ tert-butylsulfinyl)imino)-4-methoxybutan-2yl)malonate (17)

Under $\mathrm{N}_{2}$, to a solution of 14 (1.90 mmol, 0.95 equiv) in dry THF (100 mL) was added LiHMDS (1 M in THF, $4.20 \mathrm{mmol}, 2.2$ equiv) at $-78^{\circ} \mathrm{C}$. After the resulting solution was maintained at $-78{ }^{\circ} \mathrm{C}$ for $30 \mathrm{~min}$, a solution of 15 (2.00 mmol, 1.0 equiv) in THF ( $1 \mathrm{~mL})$ was slowly added for $10 \mathrm{~h}$. The resulting solution was maintained at $-78{ }^{\circ} \mathrm{C}$ for another $12 \mathrm{~h}$. The $\mathrm{dr}$ values for the first Michael addition anaylsed by LC-Ms. After the reaction was completed, the solution was quenched at $-78^{\circ} \mathrm{C}$ by pouring into aqueous $\mathrm{NH}_{4} \mathrm{Cl}(50 \mathrm{~mL})$. The aqueous layer was partitioned with EtOAc $(3 \times 50 \mathrm{~mL})$. The organic layer was separated, dried $\left(\mathrm{Na}_{2} \mathrm{SO}_{4}\right)$, filtered, and the solvent was removed in vacuo. Flash chromatography (silica gel) of the crude reaction mixture afforded pure coupled product 17 (900 mg, $80 \%$ ). Conditions for LC-MS analysis of Michael addition product: Waters ACOUITY UPLC $\mathrm{BEH} \mathrm{C} \mathrm{C}_{18}, \mathrm{BEH} \mathrm{C}_{18}(2.1 \times 100 \mathrm{~mm}, 1.7$ micron particle size), mobile phase $\mathrm{H}_{2} \mathrm{O} / \mathrm{CH}_{3} \mathrm{CN}(80: 20)$; Flow $=0.2 \mathrm{~mL} /$ min; Detected by UV at $210 \mathrm{~nm}$; Retention time for stereoisomers: $7.78 \mathrm{~min}$ (major), $8.25 \mathrm{~min}, 8.97 \mathrm{~min}$; Dr 55:1:2:0. 17: $[\alpha]_{D}^{23}-44.2\left(c \quad 0.21, \mathrm{CH}_{2} \mathrm{Cl}_{2}\right) ;{ }^{1} \mathrm{H} \quad \mathrm{NMR}$ $\left(400 \mathrm{MHz}, \mathrm{CDCl}_{3}\right) \delta$ 6.62-6.76 (m, 4H), 6.47-6.49 (m, $2 \mathrm{H}), 5.91(\mathrm{~s}, 2 \mathrm{H}), 5.86(\mathrm{~s}, 2 \mathrm{H}), 3.81-3.84(\mathrm{~m}, 1 \mathrm{H}), 3.73(\mathrm{~s}$, $3 \mathrm{H}), 3.68(\mathrm{~s}, 3 \mathrm{H}), 3.67$ (s, 3H), 3.59 (d, $J=4.0 \mathrm{~Hz}, 1 \mathrm{H})$, 2.79-3.01 (m, 1H), 2.66-2.69 (m, 4H), $0.96(\mathrm{~s}, 9 \mathrm{H}) ;{ }^{13} \mathrm{C}$ NMR $\left(100 \mathrm{MHz}, \mathrm{CDCl}_{3}\right) \delta 175.2,169.4,168.6,147.5$, $146.2,145.8,134.0,132.2,122.2,122.0,109.5,109.3$, 108.2, 108.0, 100.8, 55.6, 53.8, 53.5, 52.5, 52.4, 47.8, 42.6, 36.7, 35.4, 21.6; HRMS $[\mathrm{M}+\mathrm{Na}]^{+}$calcd for $\mathrm{C}_{29} \mathrm{H}_{35} \mathrm{NNaO}_{10} \mathrm{~S}$ 612.1874, found 612.1876; IR $(\mathrm{KBr})$ 2960, 1736, 1606, 1491, 1442, 1248, 1039, 806, 702, 591.

4.3 (3R,4R,Z)-dimethyl 3,4-bis(benzo[d][1,3]dioxol-5ylmethyl)-5-(((R)-tert-

butylsulfinyl)imino)dihydrofuran-2,2(3H)dicarboxylate (16)

Under $\mathrm{N}_{2}$, to a solution of 17 (1.82 mmol, 1 equiv) in dry THF (200 mL) was added LiHMDS (1 M in THF, $6.00 \mathrm{mmol}, 3.3$ equiv) at $-78^{\circ} \mathrm{C}$. After the resulting solution was maintained at $-78{ }^{\circ} \mathrm{C}$ for $30 \mathrm{~min}$, the 
$\mathrm{Cu}(\mathrm{OTf})_{2}(9.10 \mathrm{mmol}, 5.0$ equiv) was added at once (exposed to air for seconds). Then the reaction mixture was warmed to ambient temperature slowly and kept at $60{ }^{\circ} \mathrm{C}$ and charged with nitrogen balloon for $24 \mathrm{~h}$. After the reaction was completed, the solution was kept in room temperature and quenched by pouring it into aqueous $\mathrm{NH}_{4} \mathrm{Cl}(100 \mathrm{~mL})$. The aqueous layer was partitioned with EtOAc $(3 \times 100 \mathrm{~mL})$. The organic layer was separated and washed with with $\mathrm{HCl}(1 \mathrm{~N}, 50 \mathrm{~mL})$, water $(50 \mathrm{~mL})$ and aqueous $\mathrm{NaHCO}_{3}(50 \mathrm{~mL})$, dried $\left(\mathrm{Na}_{2} \mathrm{SO}_{4}\right)$, filtered, and the solvent was removed in vacuo. Flash chromatography (silica gel) of the crude reaction mixture afforded pure coupled product $16(860 \mathrm{mg}, 83 \%)$. $[\alpha]_{D}^{23}-77.0$ (c $0.15, \mathrm{CH}_{2} \mathrm{Cl}_{2}$ ); ${ }^{1} \mathrm{H} \mathrm{NMR}\left(400 \mathrm{MHz}, \mathrm{CDCl}_{3}\right) \delta 6.41-6.62$ $(\mathrm{m}, 6 \mathrm{H}), 5.88-5.94(\mathrm{~m}, 4 \mathrm{H}), 3.89(\mathrm{~s}, 3 \mathrm{H}), 3.84(\mathrm{~s}, 3 \mathrm{H})$, 2.61-2.91 (m, 5H), 2.13-2.17 (m, 1H), $1.10(\mathrm{~s}, 9 \mathrm{H}) ;{ }^{13} \mathrm{C}$ NMR $\left(150 \mathrm{MHz}, \mathrm{CDCl}_{3}\right) \delta 171.1,166.1,147.4,146.1$, $130.7,122.4,122.1,109.6,109.1,108.2,107.8,101.1$, 100.8, 60.4, 53.9, 53.4, 53.3, 45.8, 30.9, 22.2, 21.03, 14.2; HRMS $[\mathrm{M}+\mathrm{Na}]^{+}$calcd for $\mathrm{C}_{28} \mathrm{H}_{31} \mathrm{NNaO}_{10} \mathrm{~S} 596.1561$, found 596.1569; IR (KBr) 2962, 2926, 1749, 1665, 1504, 1492, 1445, 1364, 1260, 1088, 1039, 803.

4.4 (3R,4R)-dimethyl 3,4-bis(benzo[ $d][1,3]$ dioxol-5ylmethyl)-5-oxodihydrofuran-2,2(3H)dicarboxylate (18)

To a solution of 16 ( $0.80 \mathrm{mmol}, 1.0$ equiv $)$ in DCM (30 mL) cooled in an ice-water bath was added TFA ( $8.00 \mathrm{mmol}, 10.0$ equiv), and the mixture was stirred at room temperature for $24 \mathrm{~h}$. The reaction was quenched by the addition of sat. $\mathrm{NaHCO}_{3}$. The mixture was extracted with EtOAc $(30 \mathrm{~mL} \times 3)$, dried over $\mathrm{Na}_{2} \mathrm{SO}_{4}$ and then concentrated. The resulting residue was purified by column chromatography (silica gel) to give $\mathbf{1 8}(240 \mathrm{mg}, 80 \%)$ as a white solide. $[\alpha]_{D}^{23}$ $+8.0\left(c 0.12, \mathrm{CH}_{2} \mathrm{Cl}_{2}\right) ;{ }^{1} \mathrm{H} \mathrm{NMR}\left(400 \mathrm{MHz}, \mathrm{CDCl}_{3}\right) \delta 6.72$ $(\mathrm{d}, J=8.4 \mathrm{~Hz}, 1 \mathrm{H}), 6.59-6.67(\mathrm{~m}, 3 \mathrm{H}), 6.20-6.22(\mathrm{~m}, 2 \mathrm{H})$, $5.97(\mathrm{~d}, J=4.8 \mathrm{~Hz}, 2 \mathrm{H}), 5.91(\mathrm{~d}, J=4.6 \mathrm{~Hz}, 2 \mathrm{H}), 3.86(\mathrm{~s}$, $3 \mathrm{H}), 3.84(\mathrm{~s}, 3 \mathrm{H}), 3.03-3.10(\mathrm{~m}, 2 \mathrm{H}), 2.73-2.85(\mathrm{~m}, 2 \mathrm{H})$, $2.44-2.48(\mathrm{~m}, 1 \mathrm{H}), 2.23(\mathrm{~m}, 1 \mathrm{H}) ;{ }^{13} \mathrm{C}$ NMR $(150 \mathrm{MHz}$, $\left.\mathrm{CDCl}_{3}\right) \delta 175.6,166.8,166.7,148.0,147.5,146.6,146.3$, 130.9, 130.0, 122.6, 122.1, 109.8, 109.4, 108.3, 108.0, 101.1, $100.9,85.7,53.6,53.4,46.5,45.0,36.6,34.5$; HRMS $[\mathrm{M}+\mathrm{Na}]^{+}$calcd for $\mathrm{C}_{24} \mathrm{H}_{22} \mathrm{NaO}_{10}$ 493.1105, found 493.1107; IR (KBr) 2956, 2924, 1796, 1748, 1492, 1445, 1250, 1175, 1081, 1039, 930, 862, 810, 737, 651.

4.5 (3R,4R)-methyl 3,4-bis(benzo[ $[d][1,3]$ dioxol-5ylmethyl)-5-oxotetrahydrofuran-2-carboxylate (19)

To a solution of 18 ( $0.45 \mathrm{mmol}, 1.0$ equiv) in DMSO ( $9 \mathrm{~mL})$ was added $\mathrm{LiCl}(2.25 \mathrm{mmol}, 5.0$ equiv), and the mixture was stirred at $100{ }^{\circ} \mathrm{C}$ for $8 \mathrm{~h}$. The reaction was quenched by the addition of water $(10 \mathrm{~mL})$. The mixture was extracted with EtOAc $(10 \mathrm{~mL} \times 3)$, dried over $\mathrm{Na}_{2} \mathrm{SO}_{4}$ and then concentrated. The resulting residue was purified by column chromatography (silica gel) to give yellow oil $19(167 \mathrm{mg}, 90 \%)$ as a mixture $(\mathrm{dr} 5: 1) .{ }^{1} \mathrm{H}$ NMR (400 MHz, $\left.\mathrm{CDCl}_{3}\right) \delta 6.66(\mathrm{~d}, J=7.8 \mathrm{~Hz}, 2.4 \mathrm{H})$, $6.34-6.52(\mathrm{~m}, 4.8 \mathrm{H}), 5.92(\mathrm{~d}, J=6.5 \mathrm{~Hz}, 4.8 \mathrm{H}), 4.75(\mathrm{~d}$, $J=7.9 \mathrm{~Hz}, 0.2 \mathrm{H}$ ) (minor), $4.53(\mathrm{~d}, J=4.6 \mathrm{~Hz}, 1 \mathrm{H})$ (major), $3.78(\mathrm{~s}, 0.6 \mathrm{H}), 3.74(\mathrm{~d}, J=1.8 \mathrm{~Hz}, 3 \mathrm{H})$, 2.92-2.97 (m, 1.2H), 2.63-2.78 (m, 2.4H), $2.58(\mathrm{~m}, 3.6 \mathrm{H})$. ${ }^{13} \mathrm{C} \mathrm{NMR}\left(100 \mathrm{MHz}, \mathrm{CDCl}_{3}\right) \delta 177.2,176.7,170.0,169.1$, $147.8,146.5,131.0,130.8,130.4,130.0,122.3,122.1$, $121.7,109.6,109.4,109.3,108.9,108.3,108.2,101.1$, 78.5, 77.4, 52.7, 52.4, 45.7, 44.9, 44.5, 43.1, 38.4, 35.7, 34.9, 34.4. HRMS $[\mathrm{M}+\mathrm{Na}]^{+}$calcd for $\mathrm{C}_{22} \mathrm{H}_{20} \mathrm{NaO}_{8}$ 435.1050 , found 435.1040 .

4.6 (3R,4R)-3,4-bis(benzo[d][1,3]dioxol-5-ylmethyl)5-(hydroxymethyl)dihydrofuran-2(3H)-one (20)

To a solution of 19 (0.47 mmol, $1.0 \mathrm{eq})$ in $\mathrm{MeOH}(17 \mathrm{~mL})$ cooled in an ice-water bath was added $\mathrm{NaBH}_{4}(2.50 \mathrm{mmol}$, $2.5 \mathrm{eq}$ ), and the mixture was stirred in an ice-water bath for $10 \mathrm{~h}$. The reaction was quenched by the addition of sat. $\mathrm{NH}_{4} \mathrm{Cl}(5 \mathrm{~mL})$. The mixture was extracted with EtOAc $(10 \mathrm{~mL} \times 5)$, dried over $\mathrm{Na}_{2} \mathrm{SO}_{4}$ and then concentrated. The resulting residue was purified by column chromatography (silica gel) to give $20(140 \mathrm{mg}, 78 \%)$ as a yellow oil. ${ }^{1} \mathrm{H}$ NMR (400 MHz, $\left.\mathrm{CDCl}_{3}\right) \delta 6.70(\mathrm{~m}, \quad 2.4 \mathrm{H})$, 6.55-6.66 (m, 2.4H), $6.46(\mathrm{~d}, J=8.2 \mathrm{~Hz}, 2.4 \mathrm{H}), 5.84-5.98$ $(\mathrm{s}, 4.8 \mathrm{H}), 4.25-4.30(\mathrm{~m}, 0.2 \mathrm{H}), 4.17-4.23(\mathrm{~m}, 1 \mathrm{H}), 3.52(\mathrm{~d}$, $J=12.6 \mathrm{~Hz}, 1.2 \mathrm{H}), 3.13(\mathrm{dd}, J=12.9,4.8 \mathrm{~Hz}, 1.2 \mathrm{H})$, 2.64-2.84 (m, 2.4H), 2.36-2.50 (m, 4.8H); ${ }^{13} \mathrm{C} \mathrm{NMR}$ $\left(100 \mathrm{MHz}, \mathrm{CDCl}_{3}\right) \delta 177.4,147.8,146.4,132.1,131.3$, $122.3,121.7,121.4,109.5,108.7,108.4,108.3,108.3$, 108.1, 101.0, 83.7, 80.4, 63.1, 61.9, 47.5, 46.6, 42.0, 41.6, 38.7, 35.3, 34.8, 34.1. HRMS $[\mathrm{M}+\mathrm{Na}]^{+}$calcd for $\mathrm{C}_{21} \mathrm{H}_{20} \mathrm{NaO}_{7}$ 407.1101, found 407.1100.

4.7 ( $(3 R, 4 R)-3,4-$ bis(benzo[ $[d][1,3]$ dioxol-5ylmethyl)tetrahydrofuran-2-yl)methanol (21) and $((3 \mathrm{a} R, 13 \mathrm{a} R)-6,7,10,11-$ bis(benzo[d][1,3]dioxol)-1,3,3a,4,13,13ahexahydrodibenzo[4,5:6,7]cycloocta[1,2-c]furan1-yl)methanol (22)

To a freshly distilled $\mathrm{CHCl}_{3}$ solution $(10 \mathrm{~mL})$ was added successively 20 (0.65 mmol, 1.0 equiv), a catalytic amount of $\mathrm{InBr}_{3}$ (0.03 mmol, 0.05 equiv), and $\mathrm{Et}_{3} \mathrm{SiH}(3.25 \mathrm{mmol}$, $5.0 \mathrm{eq})$. The solution was maintained at $60{ }^{\circ} \mathrm{C}$ for $2 \mathrm{~h}$. During the stirring of the reaction mixture at $60{ }^{\circ} \mathrm{C}$ (bath 
temperature), the solution turned from colorless to yellow, then to white. The reaction was monitored by TLC until the consumption of the starting lactone. After the reaction, $\mathrm{H}_{2} \mathrm{O}(3 \mathrm{~mL})$ was added, and the resulting orange suspension was stirred continuously until the disappearance of the color. The aqueous layer was partitioned with EtOAc $(3 \times 10 \mathrm{~mL})$. The organic layer was separated, dried $\left(\mathrm{Na}_{2} \mathrm{SO}_{4}\right)$, filtered, and the solvent was removed in vacuo. Flash chromatography (silica gel) of the crude reaction mixture afforded product 21 (143 $\mathrm{mg}, 60 \%)$ and 22 (48 mg, $20 \%$ ) as a colorless oil. 21: ${ }^{1} \mathrm{H}$ NMR $(400 \mathrm{MHz}$, $\left.\mathrm{CDCl}_{3}\right) \delta 6.68(\mathrm{~m}, 2.4 \mathrm{H}), 6.54(\mathrm{~m}, 4.8 \mathrm{H}), 5.91(\mathrm{~s}, 4.8 \mathrm{H})$, $3.90-4.10(\mathrm{~m}, 0.2 \mathrm{H}), 3.82(\mathrm{td}, J=8.0,7.0,2.0 \mathrm{~Hz}, 1 \mathrm{H})$, $3.64-3.71(\mathrm{~m}, 1.2 \mathrm{H}), 3.54-3.59(\mathrm{~m}, 1.2 \mathrm{H}), 3.43(\mathrm{dd}$, $J=11.8,2.7 \mathrm{~Hz}, 1.2 \mathrm{H}), 3.23-3.37(\mathrm{~m}, 1.2 \mathrm{H}), 2.41-2.65$ (m, 4.8H), 2.13-2.25 (m, 1.2H), $1.86-1.92(\mathrm{~m}, 1.2 \mathrm{H}) ;{ }^{13} \mathrm{C}$ NMR $\left(100 \mathrm{MHz}, \mathrm{CDCl}_{3}\right) \delta 147.7,147.6,146.0,145.8$, $133.9,133.4,121.6,121.4,109.0,108.9,108.2,108.1$, $100.9, \quad 85.6, \quad 72.4, \quad 64.0, \quad 47.4, \quad 47.1, \quad 39.0$. HRMS $[\mathrm{M}+\mathrm{Na}]^{+}$calcd for $\mathrm{C}_{21} \mathrm{H}_{22} \mathrm{NaO}_{6}$ 393.1314, found 393.1317. 22: ${ }^{1} \mathrm{H}$ NMR $\left(400 \mathrm{MHz}, \mathrm{CDCl}_{3}\right) \delta 6.96(\mathrm{~s}$, $1.2 \mathrm{H}), 6.85(\mathrm{~s}, 1.2 \mathrm{H}), 6.62(\mathrm{~s}, 1.2 \mathrm{H}), 6.48(\mathrm{~s}, 1.2 \mathrm{H})$, $5.70-6.03(\mathrm{~m}, 4.8 \mathrm{H}), 4.15(\mathrm{~d}, J=7.9 \mathrm{~Hz}, 1.2 \mathrm{H}), 3.89$ (dd, $J=10.4,2.3 \mathrm{~Hz}, 1.2 \mathrm{H}), 3.53-3.78(\mathrm{~m}, 2.4 \mathrm{H}), 3.19-3.41$ $(\mathrm{m}, 1.2 \mathrm{H}), 2.55-2.98(\mathrm{~m}, 4.8 \mathrm{H}), 2.45-2.50(\mathrm{~m}, 1.2 \mathrm{H})$, 2.08-2.16 (m, 1.2H); ${ }^{13} \mathrm{C}$ NMR $\left(100 \mathrm{MHz}, \mathrm{CDCl}_{3}\right) \delta$ $146.8,146.3,146.3,145.7,139.2,135.3,130.8,127.5$, 108.6, 108.0, 105.6, 105.4, 100.9, 100.7, 77.2, 73.9, 65.2, $47.8,39.9,38.3,30.8,28.2$. HRMS $[\mathrm{M}+\mathrm{Na}]^{+}$calcd for $\mathrm{C}_{21} \mathrm{H}_{20} \mathrm{NaO}_{6} 391.1152$, found 391.1143.

\section{$4.8(3 R, 4 R)-3,4-b i s($ benzo $[d][1,3]$ dioxol-5- ylmethyl)dihydrofuran-2(3H)-one (1)}

To a solution of $21(0.08 \mathrm{mmol}, 1.0 \mathrm{eq})$ dry toluene $(3 \mathrm{~mL})$ was added PCC (0.40 mmol, $5.0 \mathrm{eq})$ and $4 \AA \mathrm{MS}(30 \mathrm{mg})$, the mixture was stirred at $80{ }^{\circ} \mathrm{C}$ for $5 \mathrm{~h}$. After the reaction, the mixture was filtered through a pad of Celite, and washed with EtOAc for 5 times and then concentrated. The resulting residue was purified by column chromatography (silica gel) to give (-)-hinokinin $1(15 \mathrm{mg}, 53 \%)$ as a white solide. $[\alpha]_{D}^{23}-31\left(c 0.21, \mathrm{CHCl}_{3}\right)$, \{lit. [5] $[\alpha]_{D}^{21}-34$ (c 2.85, $\left.\mathrm{CHCl}_{3}\right)$; lit. [21] $\left.[\alpha]_{D}^{26}-30\left(c 0.99, \mathrm{CHCl}_{3}\right)\right\} ;{ }^{1} \mathrm{H}$ NMR (400 MHz, $\left.\mathrm{CDCl}_{3}\right) \delta 6.44-6.73(\mathrm{~m}, 6 \mathrm{H}), 5.92(\mathrm{~s}$, $4 \mathrm{H}), 4.11(\mathrm{dd}, \mathrm{J}=9.0,6.7 \mathrm{~Hz}, 1 \mathrm{H}), 3.85(\mathrm{dd}, \mathrm{J}=9.2$, $6.8 \mathrm{~Hz}, 1 \mathrm{H}), 2.97(\mathrm{dd}, \mathrm{J}=14.1,5.0 \mathrm{~Hz}, 1 \mathrm{H}), 2.83(\mathrm{dd}$, $\mathrm{J}=14.1,7.3 \mathrm{~Hz}, 1 \mathrm{H}), 2.48-2.65(\mathrm{~m}, 2 \mathrm{H}), 2.45(\mathrm{~m}, 2 \mathrm{H})$. ${ }^{13} \mathrm{C}$ NMR $\left(100 \mathrm{MHz}, \mathrm{CDCl}_{3}\right) \delta 178.4,147.8,146.4,146.3$, $131.5,131.2,122.2,121.5,109.4,108.8,108.3,108.2$, $100.9,71.1,46.4,41.2,38.3,34.8$. The NMR data match those reported in the literature [3-5, 18, 21, 24, 26]. HRMS $[\mathrm{M}+\mathrm{Na}]^{+}$calcd for $\mathrm{C}_{20} \mathrm{H}_{18} \mathrm{NaO}_{6}$ 377.1001, found
377.1004; IR (KBr), 2958, 2924, 2855, 1761, 1503, 1489, 1443, 1257, 1189, 1098, 1036, 925, 864, 807, 771, 734, 676, 515.

Acknowledgments We acknowledge grant supports from Chongqing University, and the Fundamental Research Funds for the Central Universities (Project No. 0236015202004).

\section{Compliance with ethical standards}

Conflict of interest The authors declare that there is no conflict of interest.

Open Access This article is distributed under the terms of the Creative Commons Attribution 4.0 International License (http:// creativecommons.org/licenses/by/4.0/), which permits unrestricted use, distribution, and reproduction in any medium, provided you give appropriate credit to the original author(s) and the source, provide a link to the Creative Commons license, and indicate if changes were made.

\section{References}

1. D.C. Ayres, J.D. Loike, in Lignans Chemical, Biological and Clinical Properties (Cambridge University Press, Cambridge, 1990), pp. 12-17

2. R.S. Ward, Chem. Soc. Rev. 11, 75-125 (1982)

3. E. Wenkert, H.E. Gottlieb, O.R. Gottlieb, M.O.S. Pereira, M.D. Formiga, Phytochemistry 15, 1547-1551 (1976)

4. P.V. Kiem, C.V. Minh, N.T. Dat, X.F. Cai, J.L. Lee, Y.H. Kim, Arch. Pharm. Res. 26, 1014-1017 (2003)

5. M. Salmoun, J.C. Braekman, Y. Ranarivelo, R. Rasamoelisendra, D. Ralambomanana, J. Dewelle, F. Darro, R. Kiss, Nat. Prod. Res. 21, 111-120 (2007)

6. R.D. Haworth, D. Woodcock, J. Chem. Soc., 1985-1989 (1938)

7. H. Yoda, S. Naito, K. Takabe, N. Tanaka, K. Hosoya, Tetrahedron Lett. 31, 7623-7626 (1990)

8. N. Rehnberg, G. Magnusson, J. Org. Chem. 55, 4340-4349 (1990)

9. J.A. Gaboury, M.P. Sibiand, J. Org. Chem. 58, 2173-2180 (1993)

10. T. Itoh, J. Chika, Y. Takagi, S. Nishiyama, J. Org. Chem. 58, 5717-5723 (1993)

11. T. Honda, N. Kimura, S. Sato, D. Kato, H. Tominaga, J. Chem. Soc., Perkin Trans. 1, 1043-1046 (1994)

12. A. Oeveren, J.F.G.A. Jansen, B.L. Feringa, J. Org. Chem. 59, 5999-6007 (1994)

13. N. Kise, K. Tokioka, Y. Aoyama, J. Org. Chem. 60, 1100-1101 (1995)

14. M.P. Doyle, M.N. Protopopova, Q.L. Zhou, J.W. Bode, J. Org. Chem. 60, 6654-6655 (1995)

15. J.W. Bode, M.P. Doyle, M.N. Protopopova, Q.L. Zhou, J. Org. Chem. 61, 9146-9155 (1996)

16. J. Brinksma, H. Deen, A. Oeveren, B.L. Feringa, J. Chem. Soc., Perkin Trans. 1, 4159-4164 (1998)

17. S. Kamlage, M. Sefkow, B.L. Pool-Zobel, M.G. Peter, Chem. Commun., 331-336 (2001)

18. Y.M. Xia, Q.R. Liang, X.L. Wang, X.P. Cao, X.F. Pan, Chin. J. Chem. 21, 1540-1542 (2003)

19. D.J. Bennett, P.L. Pickering, N.S. Simpkins, Chem. Commun., 1392-1393 (2004)

20. T. Morimoto, H. Nagai, K. Achiwa, Synth. Commun. 35, 857-865 (2005) 
21. V.A. Souza, R. Silva, A.C. Pereira, V.A. Royo, J. Saraiva, M. Montanheiro, G.H.B. Souza, A.A.S. Filho, M.D. Grando, P.M. Donate, J.K. Bastos, S. Albuquerque, M.L.A. Silva, Bioorg. Med. Chem. Lett. 15, 303-307 (2005)

22. R. Silva, G.H.B. Souza, A.A. Silva, V.A. Souza, A.C. Pereira, V.A. Royo, M.L.A.E. Silva, P.M. Donate, A.L.S.D. Araujo, J.C.T. Carvalho, J.K. Bastos, Bioorg. Med. Chem. Lett. 15, 1033-1037 (2005)

23. N.B. Carter, R. Mabon, R. Walmsley, A.M.E. Richecoeur, J.B. Sweeney, Synlett, 1747-1749 (2006)

24. R. Kiralj, M.M.C. Ferreira, P.M. Donate, R. Silva, S. Albuquerque, J. Phys. Chem. A 111, 6316-6333 (2007)

25. Y. Xia, J. You, Y. Zhang, Z.J. Su, Chem. Res., 565-569 (2009)

26. K. Yamada, T. Konishi, M. Nakano, S. Fujii, R. Cadou, Y. Yamamoto, K. Tomioka, J. Org. Chem. 77, 5775-5780 (2012)

27. X. Lin, B.R. Switzer, W. Denmark-Wahnefried, Anticancer Res. 21, 3995-3999 (2001)

28. J. Peterson, J. Dwyer, H. Adlercreutz, A. Scalbert, P. Jacques, M.L. McCullough, Nutr. Rev. 68, 571-603 (2010)

29. L. Wilson, M. Friedkin, Biochemistry 6, 3126-3135 (1967)

30. J.K. Kelleher, Mol. Pharm. 13, 232-241 (1977)

31. J.D. Loike, C.F. Brewer, H. Sternlicht, W.J. Gensler, S.B. Horwitz, Cancer Res. 38, 2688-2693 (1978)

32. C.F. Brewer, J.D. Loike, S.B. Horwitz, H. Sternlicht, W.J. Gensler, J. Med. Chem. 22, 215-221 (1979)

33. F. Zavala, D. Guenard, J.P. Robin, E. Brown, J. Med. Chem. 23, 546-549 (1980)

34. P. Potier, Chem. Soc. Rev. 21, 113-119 (1992)

35. X.K. Zhu, J. Guan, Y. Tachibana, K.F. Bastow, S.J. Cho, H.H. Cheng, Y.C. Cheng, M. Gurwith, K.H. Lee, J. Med. Chem. 42, 2441-2446 (1999)

36. K. Tomioka, T. Ishiguro, H. Mizuguchi, N. Komeshima, K. Koga, S. Tsukagoshi, T. Tsuruo, T. Tashiro, S. Tanida, T. Kishi, J. Med. Chem. 34, 54-57 (1991)

37. J.X. Pan, O.D. Hensens, D.L. Zink, M.N. Chang, S.B. Hwang, Phytochemistry 26, 1377-1379 (1987)

38. D.A. Whiting, Nat. Prod. Rep. 2, 191-211 (1985)

39. D.A. Whiting, Nat. Prod. Rep. 4, 499-525 (1987)
40. D.A. Whiting, Nat. Prod. Rep. 7, 349-364 (1990)

41. R.S. Ward, Nat. Prod. Rep. 10, 1-28 (1993)

42. R.S. Ward, Nat. Prod. Rep. 12, 183-205 (1995)

43. R.S. Ward, Nat. Prod. Rep. 14, 43-74 (1997)

44. R.S. Ward, Nat. Prod. Rep. 16, 75-96 (1999)

45. R.S. Ward, Tetrahedron 46, 5029-5041 (1990)

46. R.S. Ward, Synthesis, 719-730 (1992)

47. D. Enders, V. Lausberg, G.D. Signore, O.M. Berner, Synthesis 4, 515-522 (2002)

48. H.J. Wang, P. Tang, Q.L. Zhou, D. Zhang, Z.T. Chen, H.X. Huang, Y. Qin, J. Org. Chem. 80, 2494-2502 (2015)

49. G. Blay, L. Cardona, B. García, L. Lahoz, J. Pedro, Tetrahedron 52, 8611-8618 (1996)

50. O. Yabe, H. Mizufune, T. Ikemoto, Synlett, 1291-1294 (2009)

51. M. Noè, A. Perosa, M. Selva, Green Chem. 15, 2252-2260 (2013)

52. F. Colpaert, S. Mangelinckx, G. Verniest, N.D. Kimpe, J. Org. Chem. 74, 3792-3797 (2009)

53. T. Kochi, J.A. Ellman, J. Am. Chem. Soc. 126, 15652-15653 (2004)

54. T.D. Owens, A.J. Souers, J.A. Ellman, J. Org. Chem. 68, 3-10 (2003)

55. C. Su, Z.C. Chen, Q.G. Zheng, Synthesis, 555-559 (2003)

56. H. Mukherjee, C.A. Martinez, ACS Catal. 1, 1010-1013 (2011)

57. A.P. Krapcho, G.A. Glynn, B.J. Grenon, Tetrahedron Lett. 8, 215-217 (1967)

58. A.P. Krapcho, E.G.E. Jahngen, A.J. Lovey, F.W. Short, Tetrahedron Lett. 15, 1091-1094 (1974)

59. A.P. Krapcho, J.F. Weimaster, J.M. Eldridge, E.G.E. Jahngen, A.J. Lovey, W.P. Stephens, J. Org. Chem. 43, 138-147 (1978)

60. N. Sakai, T. Moriya, T. Konakahara, J. Org. Chem. 72, 5920-5922 (2007)

61. N. Sakai, T. Moriya, K. Fujii, T. Konakahara, Synthesis 21, 3533-3536 (2008)

62. S. Baskaran, S. Chandrasekaran, Tetrahedron Lett. 31, 2775-2778 (1990)

63. S.M. Ali, K. Ramesh, R.T. Borchardt, Tetrahedron Lett. 31, 1509-1512 (1990) 